\author{
DEPARTMENT OF THE INTERIOR \\ UNITED STATES GEOLOGICAL SURVEY
}

PREPARED IN COOPERATION WITH THE

STATE OF CONNECTICUT

GEOLOGICAL AND NATURAL HISTORY SURVEY

\title{
AEROMAGNETIC MAP OF THE LONG HILL. QUADRANGLE AND PART OF THE BOTSFORD QUADRANGLE, FAIRFIELD AND \\ NEW HAVEN COUNTIES, CONNECTICUT
}

\author{
GEOPHYSICAL INVESTIGATIONS \\ MAP GP-871
}

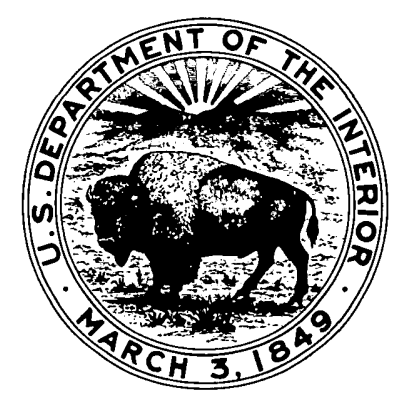

PUBLISHED BY THE U.S. GEOLOGICAL SURVEY 